\title{
Incest or Adoption? Brother-Sister Marriage in Roman Egypt Revisited*
}

\author{
SOFIE REMIJSEN AND WILLY CLARYSSE
}

\section{INTRODUCTION}

In official and notarial papyrus documents from the Roman period in Egypt, women are regularly presented as 'wife and sister from the same father and the same mother' as their husbands. According to the traditional view, this sentence 'leaves little room for ambiguity'. ${ }^{1}$ Brother-sister marriages in Roman Egypt seem to defy a universal rule, for in nearly all societies marriage between a full brother and sister is taboo. This strange phenomenon causes general surprise as it not only collides with our own values, but we also know the negative genetic effects of such incestuous relations. Therefore, papyrologists and ancient historians have presented evidence that such marriages were indeed practised, with a 'vaguely prurient pleasure'. ${ }^{2}$

Thus far, no one has been able to explain convincingly why the universal taboo on incest was violated in Roman Egypt. Recently, Huebner has argued that brother-sister marriages were not incestuous at all. ${ }^{3}$ In her view, these were not marriages between a natural brother and sister, but between an adopted and a natural child. The central argument, which makes this thesis so attractive, is that marrying an adopted son to a natural daughter was a widespread family strategy documented all over the eastern Mediterranean. The formula 'wife and sister from the same father and the same mother' is - on her view - a juridical fiction, disguising this family strategy, and should not be taken at face value.

We fully agree with Huebner that adoption and marrying an adopted son to a natural daughter were common practices in the eastern Mediterranean and that adoption was probably more frequent in Egypt than our sources suggest. We doubt, however, that marriage between natural and adopted children explains brother-sister marriage. In the first part of this paper we shall argue that ancient authors considered brother-sister marriage as a peculiarity of the whole Egyptian population. In the second part we shall argue that papyrological sources do not prove any connection between adoption and brother-sister marriage and rather suggest that full brothers really married their sisters.

\section{THE LITERARY SOURCES}

The reason why the relation between brother-sister marriage and adoption as a family strategy was never recognized before is due, according to Huebner, to a problem of documentation. Whereas legal speeches from Athens and inscriptions from Asia Minor inform

\footnotetext{
We would like to thank Dorothy Thompson for correcting our English and offering invaluable comments. We also profited from suggestions by Mark Depauw and Katelijn Vandorpe.

1 Keith Hopkins, 'Brother-sister marriage in Roman Egypt', Comparative Studies in Society and History. An International Quarterly 22 (I980), $32 \mathrm{I}$.

2 Sabine R. Huebner, "Brother-sister" marriage in Roman Egypt: a curiosity of humankind or a widespread family strategy?', JRS 97 (2007), 2I.

3 Huebner, op. cit. (n. 2), $2 \mathrm{I}-49$.
} 
us about adoption, papyri teach us very little about this. ${ }^{4}$ About brother-sister marriage, on the other hand, the papyri, especially census returns from the Roman period mentioning the name of both father and mother, are our main source. But on the basis of the census returns, it cannot be proved that the brother-sister marriage was typical of Roman Egypt, since such sources are not available for other periods and areas. It is indeed important not to confuse the spread of a phenomenon with the diffusion of the sources available.

To decide whether brother-sister marriage only disguises a widespread family strategy, or is a reality of Roman Egypt, we need a form of documentation that the whole eastern Mediterranean has in common. Here the importance of the ancient authors who discuss marriage customs in the whole ancient world is downplayed by Huebner, who mentions only Diodorus and Philo. Six authors, Greek and Latin, clearly present brother-sister marriage as a typical Egyptian custom. One could argue that they were all just repeating the same stereotype, but did the stereotype hint at the weddings in the royal family, as Huebner suggests, or at a common Egyptian practice?

The earliest literary evidence for brother-sister marriage is Diodorus (c. 60-30 в.с.). ${ }^{5}$ In a discussion of Egyptian curiosities, such as the reckoning of time, he mentions a law that, contrary to the general custom of humankind, permits brothers to marry their sisters. He explains this strange custom by the example of Isis and Osiris.

Commenting on the sixth commandment ('Thou shalt not commit adultery'), the Alexandrian Jew Philo (flor. c. A.D. 20-50) mentions brother-sister marriage as one form of forbidden relations. ${ }^{6}$ Some pagans permit this form of incest: Solon allowed the Athenians to marry a sister of the same father, but not of the same mother, while the Spartan lawgiver allowed the opposite. The Egyptian lawgiver permitted men to marry every kind of sister, even a twin sister. Moses, however, prohibited all incestuous relations. ${ }^{7}$

In his Apocolocyntosis (shortly after A.D. 54), a satire on the deification of Claudius, Seneca mentions Egyptian brother-sister marriage in connection with a contemporary case of incest between a brother and sister, punished by Claudius: 'You moron, you should study more: in Athens this is permitted half, in Alexandria completely!'8 Seneca's introductory words imply that he considers this information basic knowledge among his Roman readers. He expects them to understand the joke.

Pausanias (flor. c. A.D. I65-I80) says about the marriage between Ptolemy II and his sister Arsinoe, that Ptolemy violated Macedonian custom, but followed his Egyptian subjects. ${ }^{9}$

The physician and sceptic Sextus Empiricus (c. A.D. 200) argues that everything is relative, giving a long list of examples showing that practices deemed shameful by some, are not necessarily deemed shameful by others. A man may think, for instance, that it is sinful to marry his mother or sister, but the Persian Magi marry their mothers and the Egyptians their sisters, as did Zeus. ${ }^{10}$ Of all the examples, it is Egyptian brother-sister

\footnotetext{
4 The papyrological evidence for adoption is presented in Marek Kurylowicz, 'Adoption on the evidence of the papyri', Journal of Juristic Papyrology I9 (I983), 6I-75 and Bernard Legras, 'L'adoption en droit hellénistique, d'après les papyrus grecs d'Égypte', in Alain Bresson et al. (eds), Parenté et société dans le monde grec de l'Antiquité à l'âge moderne (2006), I75-88. See also Huebner, op. cit. (n. 2), 33-40.

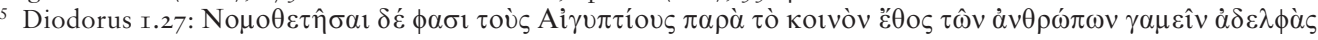

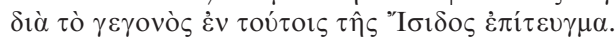

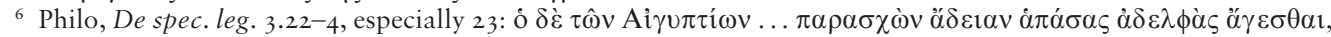

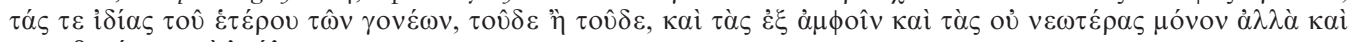

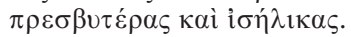

7 We cannot date the Egyptian lawgiver on the basis of Philo. As is clear from the examples of Athens and Sparta, he does not imply that the lawgiver of the Egyptians was a contemporary of Moses, as Huebner, op. cit. (n. 2), 23, suggests.

8 Seneca, Apocolocyntosis 8: 'Stulte, stude. Athenis dimidium licet, Alexandriae totum.'

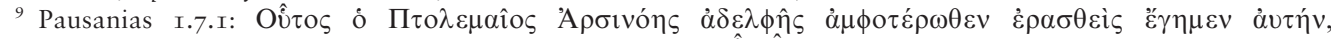

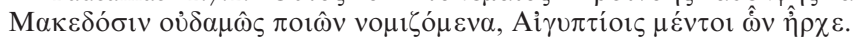

10 Sextus Empiricus, Outlines of Pyrrhonism 3.205. Cf. I.I52.
} 
marriage that he returns to in his conclusion: 'If we did not know, by chance, about the custom of the Egyptians of marrying their sisters, we would have asserted wrongly that it was universally agreed that men ought not to marry their sisters' ${ }^{11}$

The Christian author Minucius Felix (early third century A.D.) wrote a dialogue between the Christian Octavius and a pagan opponent. Against the pagan accusation that Christian banquets are incestuous orgies, Octavius objects that pagans, not Christians, commit incest: 'Among the Persians it is legal to marry your mother, for the Egyptians and in Athens a marriage with a sister is legitimate'. ${ }^{12}$

As Hopkins has already observed, none of these sources tell us how common brothersister marriage actually was. ${ }^{13}$ Analysing Diodorus and Philo, Huebner adds that 'both stories should indicate to us that it was not a custom widely practised among the Egyptian population in the Hellenistic period'. ${ }^{14}$ She argues that Diodorus and Philo followed Hecataeus of Abdera and Manetho, two authors who wanted to legitimize the Ptolemaic claim to Egypt and, therefore, perhaps tried to cover for Ptolemy II's incestuous marriage by presenting it to the Greeks as an Egyptian habit. This, however, is hardly convincing. Her argument is based on two hypotheses. Firstly, we do not know for sure that Diodorus and Philo relied on Hecataeus and Manetho for their information about brother-sister marriage. Other sources are possible, certainly for Philo, who, as an Alexandrian, might even have known married brothers and sisters. Secondly, we do not know how Hecataeus and Manetho reacted to the incestuous marriage of their king. The official version compared the marriage to that of Zeus and Hera, thus claiming a unique, divine prerogative for the king. ${ }^{15}$ This account would give Ptolemy a better legitimation, for an Egyptian law could not really justify a Greek king in the eyes of Greek moralists.

Although no author explicitly states that brother-sister marriage was practised outside the royal family, to claim that they actually indicate that it was not common goes too far. For if the literary sources indicate anything, it is exactly the opposite. All six authors present the possibility of marrying a full sister as a rule applying to all Egyptians, parallel to the Athenian law permitting Athenian citizens to marry their half-sister from the same father. An indirect indication that such a law did indeed exist can be found in the Gnomon of the Idios Logos. This collection, containing laws for every population group (Romans, Alexandrians, Egyptians), forbids only Romans from marrying their sisters. ${ }^{16}$ If brothersister marriages were only practised by the kings and were taboo for their subjects, no law would have been needed. Moreover, as a royal prerogative, brother-sister marriage was not typical of Egypt, since kings from outside Egypt also married their sisters. ${ }^{17}$

Several details confirm this interpretation. None of the authors suggest that the custom was abandoned in their own time. By using the present tense, Seneca and Minucius Felix

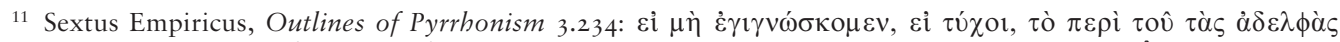

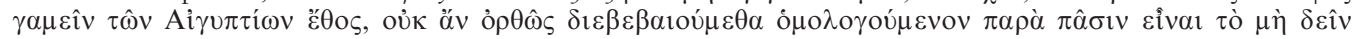
$\dot{\alpha} \delta \varepsilon \lambda \phi \grave{\alpha} \zeta \gamma \alpha \mu \varepsilon \hat{\imath} v$.

${ }^{12}$ Minucius Felix, Octavius 3I: 'Ius est apud Persas misceri cum matribus, Aegyptiis et Athenis cum sororibus legitima conubia.'

${ }_{13}$ Hopkins, op. cit. (n. I), 3I2. In this article he makes no mention of Sextus Empiricus. He adds the reference in a later article, commenting that Sextus Empiricus' words indicate that brother-sister marriage was apparently widely dispersed among all sectors of Egyptian society (Keith Hopkins, 'Le mariage frère-soeur en Égypte romaine', in Pierre Bonte (ed.), Epouser au plus proche. Inceste, probibitions et stratégies matrimoniales autour de la Méditerranée, Civilisations et Sociétés 89 (I994), 77-95, especially 8I). However, Sextus Empiricus does not report how common it was either.

${ }^{14}$ Huebner, op. cit. (n. 2), 23.

15 This comparison is made by the court poet Theocritus, Idyll I7.I28-34.

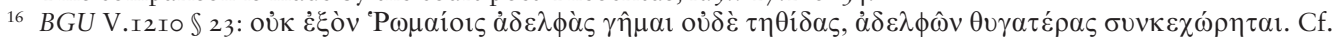
Erwin Seidl, Rechtsgeschichte Ägyptens als römischer Provinz (I973), 2I6-I7.

17 For examples in Caria, Persia, etc., see Simon Hornblower, 'Hekatomnid sister-marriage', in idem, Mausolos (I982), 358-63.
} 
present the rule as still valid. Philo stresses that men even married their twin sisters, ${ }^{18}$ a detail meaningless in the royal context, since there were no Ptolemaic brother-sister marriages between twins. According to Pausanias, Ptolemy followed the example of his

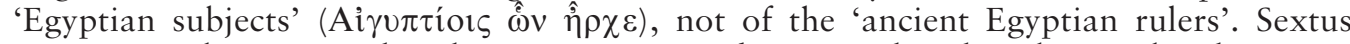
Empiricus' observation that the Egyptian example proves that the taboo on brother-sister marriages is not universal, only makes a strong and conclusive argument if it was relatively frequent in Egypt.

Although the papyrological evidence does not by itself prove that brother-sister marriage was typical of Egypt, the literary sources point in the same direction. The authors who discuss the subject present brother-sister marriage as a common Egyptian practice, not as a juridical fiction and not as a royal prerogative. All stress the continuity with the Egyptian past. Our conclusion, however, only concerns the Roman period. For earlier periods the evidence simply does not suffice. ${ }^{19}$

\section{THE PAPYROLOGICAL EVIDENCE}

Huebner convincingly argues that adoption was more common in Roman Egypt than is generally believed. Although adoption seems under-represented in the papyri, ${ }^{20}$ two telling statistics confirm her thesis. ${ }^{21}$ (I) According to model life tables only 50 to 66 per cent of all men above fifty had a male heir. In the surviving census returns, however, 49 out of 56 men over fifty $(87.5$ per cent) register an heir. This number is surprisingly high, the more so because the census returns do not list all sons, but only those living in the same household as their father. This could be explained by adoption. (2) In her second statistic, Huebner points out that the census returns also register a remarkably high number of coeval siblings. Considering the high mortality rate of twins, these cannot all be actual twins. One child of each pair of coeval siblings might then be adopted. Probably only the few coeval siblings explicitly called 'twins' are really biologically related.

Though pointing to the existence of adoption as a family strategy in Egypt, these data cannot prove that there was a connection between adoption and brother-sister marriage, because they do not coincide with the known brother-sister marriages: (I) only six of the above-mentioned 49 heirs are married to their (half-) sister and (2) none of those coeval siblings from the census returns are married to each other. One declaration on papyrus mentions a coeval brother-sister couple: Sabinus and his 'wife and twin sister' Thermion, but since they are explicitly called twins - and thus, according to Huebner, biologically related — this case cannot be explained by adoption. ${ }^{22}$

The strongest argument in favour of a connection between adoption and brother-sister marriage is that marrying an adopted son to a natural daughter was a common family strategy in the whole eastern Mediterranean in antiquity. Thus, in order to check if there was really a connection, we need to examine whether Egyptian brother-sister marriages followed the adoption pattern attested elsewhere.

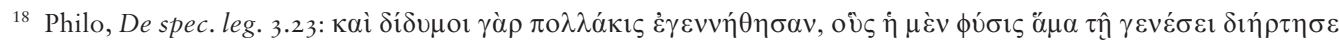

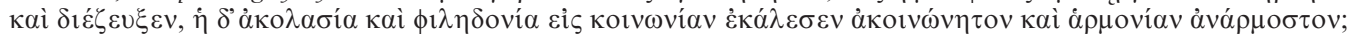
'For frequently twins are born, whom nature has separated and divided at birth, but whom licentiousness and fondness of pleasure has brought to incongruous intercourse and improper union.'

19 For the Ptolemaic period Diodorus is the only literary source. In addition, there are three papyrus texts with brother-sister marriages (SB XII.I I053, P.Tebt. III.766 and P.Grenf. II.26), but only P.Tebt. III.766 (I 47 or I 36 B.C.) is beyond doubt.

20 See note 4 .

21 Huebner, op. cit. (n. 2), 36-8.

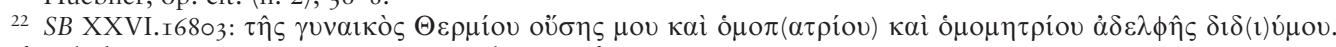
Cf. Nikolaos Gonis, 'Incestuous twins in the city of Arsinoe', ZPE I33 (2000), I97-8.
} 
Adoption, as a family strategy in the eastern Mediterranean, had the following characteristics: ${ }^{23}$

(I) The most common reason for adoption was preserving the oikos. Childless couples or couples with only daughters needed a male heir. Other reasons played only a minor role.

(2) As a result, at least 90 per cent of the adoptees were male. ${ }^{24}$ Though possible, adoption of females was rare. If a woman was adopted, she often already had a son, who would inherit the oikos in her place.

(3) Many adoptees were somehow related to their adoptive father.

(4) Most adoptees were adopted as adults. Couples usually postponed adoption until they were too old to produce an heir of their own. The best guarantee for the preservation of the oikos and for care during their old age was a healthy young man.

(5) Adoptees kept their proper name after adoption, but received a new patronymic.

If Egyptian brother-sister marriage fits this strategy, one would expect that:

(I) In at least 90 per cent of the cases the brother would be the adoptee.

(2) Most adoptees would be the only sons of their adoptive parents.

(3) Most adoptees would not have the same name as their adoptive paternal grandfather.

Expectations (2) and (3) can be verified in the papyri. ${ }^{25}$ If confirmed, they support Huebner's thesis. If not, Egyptian brother-sister marriage does not follow the adoption pattern of the rest of the eastern Mediterranean and Huebner's strongest argument is invalidated. Our tabulation of the surviving data below is aimed at answering this question.

Table I shows the number of sons and daughters in each household with a son and daughter married to each other (brother-sister marriage in second generation). We also include households in which the married brother and sister are the parents (brother-sister marriage in first generation), but only if other brothers or sisters are registered. These are minimum figures: only sons and daughters living in the same household are mentioned. Other children may have left the household. Surprisingly brother-sister marriages often occur in rather large families with on average 2.53 sons and 1.63 daughters living at home. The preponderance of sons can be explained by the virilocal marriage pattern. In fourteen out of nineteen families there is at least one other male heir and, therefore, these families had no need to adopt.

The third expectation, i.e. the onomastic argument, needs some further clarification. The custom of naming the eldest son after his paternal grandfather was widespread in antiquity. ${ }^{26}$ Consequently, in many families two names alternated between the generations. In Roman Egypt, about 23 per cent of all men had the same name as their paternal

\footnotetext{
${ }^{23}$ In general: Huebner, op. cit. (n. 2), 27-40. For Athens: Lene Rubinstein, Adoption in IV. Century Athens (I993). For Rhodes: G. Poma, 'Ricerche sull'adozione nel mondo rodio (III sec. a.C. / III sec. d.C.)', Epigraphica 34 (I972), I69-305; Eftychia Stavrianopoulou, 'Die Frauenadoption auf Rhodos', Tyche 8 (I993), I77-88.

${ }^{24}$ For Athens: in Rubinstein's list (op. cit. (n. 23), II7-33), 3 of 36 adoptees are female (8 per cent). For Rhodes: in Poma's list (op. cit. (n. 23), 210-69), I8 of 493 adoptees (4 per cent). In a more recent article, Stravianopoulou (op. cit. (n. 23), I78) gives 23 cases of the adoption of a woman on Rhodes.

${ }_{25}$ We have taken account of all census returns listed in Roger S. Bagnall and Bruce W. Frier, The Demography of Roman Egypt (I994), in the supplement of 2006, and in Roger S. Bagnall, Bruce W. Frier and Ian C. Rutherford, The Census Register P. Oxy. 984: The Reverse of Pindar's Paeans, Papyrologica Bruxellensia 29 (I997). Other texts are not used for this table, since they give little information about the composition of the household.

26 Deborah Hobson, 'Naming practices in Roman Egypt', BASP 26 (I989), I65; Willy Clarysse and Dorothy J. Thompson, Counting the People in Hellenistic Egypt, II (2006), 329.
} 
TABLE I. Number of sons and daughters in households with a son and daughter married to each other $(*=$ half-siblings). The married son and daughter are included.

\begin{tabular}{|c|c|c|}
\hline Census return & Sons & Daughters \\
\hline II7-Ar-I & I & 2 \\
\hline I 3 I-He- $4 *$ & I & I \\
\hline I $45-\mathrm{Ar}-9$ & I & 3 \\
\hline I45-Ar-I9 & 4 & $2(3 ?)$ \\
\hline $\mathrm{I} 45-\mathrm{Ar}-20$ & I & I \\
\hline I59-Ar-4 & 3 & 2 \\
\hline I 59-Ar-5 & $4(?)$ & I \\
\hline I59-Ar-II & I & I \\
\hline I73-Ar-9 & 2 & I \\
\hline I73-Ar-II & 2 & I \\
\hline I73-Ar-2I & 3 & I \\
\hline I73-Pr-5 & 3 & 2 \\
\hline I73-Pr-IO & 4 & I $(2 ?)$ \\
\hline I $87-\mathrm{Ar}-4$ & 2 & I \\
\hline I $87-\mathrm{Ar}-4$ & 5 & 3 \\
\hline I87-Ar-4 & 3 & I \\
\hline I87-Ar-8* & 3 & 3 \\
\hline I $87-\mathrm{Ar}-22 *$ & 2 & 3 \\
\hline $2 \mathrm{I} 5-\mathrm{Hm}-\mathrm{I}=229-\mathrm{Hm}-\mathrm{I}$ & 3 & I \\
\hline
\end{tabular}

grandfather. ${ }^{27}$ Likewise, the second son was sometimes named after his maternal grandfather. Therefore, about ro per cent of the men in Roman Egypt had the same name as their mother's father. ${ }^{28}$ Naming a son after his father was another option.

In the eastern Mediterranean, when a man was adopted, he kept his proper name. This was also the case for Egypt. Although there are only a few examples of adopted sons with a full stemma, including a grandfather, several examples illustrate that the onomastic pattern followed the blood line: in P.Oxy. I.46 (A.D. IOO), Harthothes son of Peteharbebekis grandson of Harthothes is adopted by Ampendis; in SB XVIII.I3I76 (A.D. I68), Diogenes son of Hermaios grandson of Diogenes is adopted by Syrion. Both kept the name of their natural grandfather. In P.Oxy. XXXI.2583 (second century A.D.), Diophantos son of Herakleios is called after his natural grandfather Diophantos, whereas the name of his adopted brother Horion does not appear in the family line (his lineage is not given). In P.Merton I.I8 (A.D. I6I), Sarapion is named after his natural father Sarapion, not after his adopted father Kleochares; similarly Harpokration son of Harpokration in P.Oxy. LXVI.453I (A.D. I96).

The typical Egyptian habit of double names offered an interesting possibility for adoptees: they could keep their proper name, given at birth, and could take the name of the adopter's father as a second name, after being adopted. This habit is attested in $S B$

\footnotetext{
${ }^{27}$ In the census returns the paternal grandfather is attested for 368 men, of whom 18 are married to their sister. Of the other 350,80 are named after their paternal grandfather, i.e. 23 per cent. Hobson, op. cit. (n. 26), I66-8, comes to similar results using three different data sets: 2 I per cent of II7 men from the census returns, 30 per cent of 234 men from P.Lond. II.257-60, 25 per cent of 96 men from Soknopaiou Nesos.

28 The maternal grandfather is known for I94 of the 350 men from the census returns (see preceding note), of whom twenty (Io per cent) are named after him.
} 
XX.I4395 (A.D. I8I): Artemidoros alias Diogenes son of Polykrates grandson of Artemidoros is adopted by Papontos son of Diogenes. Note that the real grandfather's name precedes. P.Oxy. XIV.I72I (A.D. I87) is probably a similar case: Theon alias Hermias, whose father is not mentioned, uses as his second name the name of his adoptive father and grandfather, both called Hermias.

In other texts, the adoptive sons do not share their name with a member of their natural or adoptive family. Only Didymos son of Theon has the same name as his adoptive father Didymos in P.Oxy. XIV.I7I9 (A.D. 204). This is, however, not surprising. Since many adoptees were somehow related to their adoptive father, the proper name of the adoptee, given by his natural parents, might occur in the family of the adopter as well.

However, name identity of a man with his grandfather can help us to distinguish natural from adopted sons, since it is far more likely that a natural son bore the name of his real paternal grandfather than that an adopted son bore that of his adoptive grandfather. ${ }^{29}$ For Roman Egypt we expect name identity for about 23 per cent of the natural sons and only occasionally for adopted sons. In Athens we find similar results: of the twenty known adoptive grandfathers from Athens, only one has the same name as the adoptee (5 per cent), but of the eleven known natural grandfathers, three have the same name as their grandson (27 per cent).

The second table shows for each brother-sister marriage the name of the husband (the presumed adoptee) and of his paternal grandfather (the father of the presumed adopter). The table is based on all papyri for which both names are known. ${ }^{30}$ In twelve out of thirtyseven cases, i.e. 32 per cent, the presumed adoptees have the same name as the father of their presumed adopter. ${ }^{31}$ If we exclude brother-sister marriages between half-siblings (from returns marked * in Table 2 ), which are not taken into account by Huebner, the result is similar (30 per cent). This is a perfectly normal situation for natural sons, but does not fit the adoption model.

Neither the household size nor the onomastic pattern are consistent with the usual adoption practices. Since the differences are substantial, the possibility that some (i.e. less than Io per cent) of the adoptees might be female is not enough of an explanation. If brother-sister marriage was indeed the result of adoption, the Egyptian adoption strategy was clearly different from elsewhere in the eastern Mediterranean. Since the existence of a widespread family strategy was the main argument in favour of a connection between brother-sister marriage and adoption, such a connection is, in our opinion, unproven. Therefore, we are thrown back upon the literal interpretation of our sources, and for the time being must accept that Egyptians did marry their sisters. As long as there is no proof for a hidden meaning, we have to take our sources at face value.

Our conclusions bring us back to the traditional view: the incestuous marriages recorded in the literary and papyrological sources remain baffling — in the words of Huebner 'a curiosity of humankind'. Modern scholars have sought an explanation in two different directions. Some looked for a singularity in Egyptian society, but the one singularity that can convincingly explain how this strange habit came into being is still to

\footnotetext{
${ }^{29}$ Many adoptees were somehow related to their adopter, but the chance that the adoptee has the same name as his adoptive grandfather is only considerable if the adoptee is a nephew of the adopter: if the adoptee is the son of a brother of the adopter, his natural and adoptive grandfather are the same person, and consequently, name identity occurs in 23 per cent of the cases (cf. note 27); if the adoptee is the son of a sister of the adopter, his adoptive paternal grandfather is his natural maternal grandfather and name identity occurs in Io per cent of the cases (cf. note 28). But only some of the adoptees are nephews of their adopters, e.g. 9 per cent in Athens (Rubinstein, op. cit. (n. 23), nos 7, I5 and 23). When the adoptee and the adopter are otherwise related, the chance of name identity is almost as small as for complete strangers.

${ }^{30}$ For the census declaration, see note 25. For the other texts we employ the list of Silvia Bussi, 'Mariages endogames en Égypte hellénistique et romaine', Revue Historique de Droit Français et Étranger 80 (2002), I-22.

31 All instances of name identity are put in italics. Because Ptollas is a hypocoristic of Ptolemaios, I73-Ar-9 can be considered as a thirteenth case of name identity.
} 
TABLE 2. Names of the presumed adoptees and of the fathers of the presumed adopters

\begin{tabular}{|c|c|c|}
\hline CENSUS RETURNS & Presumed adoptee & FATHER OF PRESUMED ADOPTER \\
\hline I3I-He-4 * & Psois & Piathres \\
\hline $145-\mathrm{Ar}-9 *$ & Chares & Dionysios \\
\hline I $45-A r-9$ & Atarias & Atarias \\
\hline $\mathrm{I} 45-\mathrm{Ar}-20$ & Panephremmis & Panephremmis \\
\hline I $59-\mathrm{Ar}-4$ & Herodes & Herodes \\
\hline I59-Ar-II & Petheus & Petheus \\
\hline I59-Ar-II & Isidoros & Isidoros \\
\hline I73-Ar-2 * & Mesoeris & Satabous? \\
\hline I73-Ar-9 & Ptollas & Ptolemaios \\
\hline I73-Pr-5 & Phibis & Phibis \\
\hline I73-Pr-IO & Tithoennesis & Pnepheros \\
\hline I $87-\mathrm{Ar}-4$ & Herodes & Herakleides \\
\hline I $87-\mathrm{Ar}-4$ & Heron & Heron \\
\hline I87-Ar-4 & Heron & Heron \\
\hline I87-Ar-I2 & Didymos & Souchas \\
\hline I87-Ar-22 * & Eutyches & Theon \\
\hline 2I 5-Hm-I, 229-Hm-I & Aurelius Theognostos alias Moros & Achilleus \\
\hline \multicolumn{3}{|l|}{ OTHER TEXTS } \\
\hline P.Amh. II.75 & Hermaios & Areios \\
\hline P.Amh. II.75 & Areios & Areios \\
\hline P.Amh. II.75 & Hermaios & Hermaios \\
\hline$B G U$ I.I83 & Horos & Tesenouphis \\
\hline$B G U$ XI.2094 & Satabous & Apynchis \\
\hline CPR I.28 & Apollonios & Kastor \\
\hline M.Chr. 204 & Herodes/Petenephris & Chairemon \\
\hline P.Kron. & Harphaesis & Cheos \\
\hline P.Kron. & Kronion & Cheos \\
\hline P.Mich. V.262, 266 & Didymos & Didymos \\
\hline P.Oxy. III.477 & Ammonios & Sarapion \\
\hline P.Oxy. XII.I452 & Sarapion & Diodoros \\
\hline P.Oxy. XLIII.3096 & Diogenes/Pausirion & Amois \\
\hline P.Stras. VI.505 & Ischyrion & Maron \\
\hline P.Tebt. II.3I7 & Herakleios & Onnophris \\
\hline P.Tebt. II. 320 & Eudaimon & Souchas \\
\hline SB VI.93I7 & Petenephotes & Sarapas \\
\hline SB XII.10890 & Herakleides & Chairemon \\
\hline SB XVIII.I3958 & Artemidoros & Artemidoros/Adrastos \\
\hline SB XXVI.I6803 & Sabinus & Herak... \\
\hline
\end{tabular}


be found. ${ }^{32}$ Others, like Huebner, tried to put the custom in a broader regional context. We have argued that the brother-sister marriage is not connected to the context of adoption, but there are other possible contexts. It has long been observed that marriages between close relatives were favoured all over the eastern Mediterranean. ${ }^{33}$ In Athens marriage between paternal half-siblings was tolerated, in Sparta between maternal halfsiblings. That in Egypt marriages between both maternal and paternal half-siblings were acceptable has never been put into question. Seen in this light, marrying full-siblings was perhaps not such a big step in Egypt as it seems to us. Against the background of our own value system, however, perhaps no explanation of the phenomenon can ever be entirely satisfactory.

University of Leuven

sofie.remijsen@arts.kuleuven.be

willy.clarysse@arts.kuleuven.be

${ }^{32}$ Huebner, op. cit. (n. 2), 22-7, presents good coverage of the status quaestionis; see further, Bernard Vernier, 'Prohibition de l'inceste, mariage entre très proches parents et place de la femme dans les rapport entre les sexes. Le cas de l'ancienne Égypte', La Pensée 339 (2004), II7-34.

33 cf. Bonte, op. cit. (n. I3), or, one of the first to observe this tendency, Egon Weiß, 'Endogamie und Exogamie im römischen Kaiserreich', Zeitschrift der Savigny-Stiftung für Rechtsgeschichte. Rom. Abt. 29 (I902), 340-69. 